\title{
PENGARUH POWER TUNGKAI DAN MINAT TERHADAP HASIL BELAJAR SMASH OLAHRAGA BOLA VOLI PADA SISWA KELAS VI SDN MARGAJAYA I
}

\author{
P-ISSN: 2089-4341 | E-ISSN: 2655-9633 \\ Link: https://uia.e-journal.id/akademika/article/view/815 \\ DOI: 10.34005 /akademika.v9i01.815
}

\section{Yan Yan Julian}

yanjulian3@gmail.com

SDN Margajaya I Kota

Bekasi Indonesia

\author{
Khasanah \\ khasanahrazali@yahoo.com \\ Universitas Islam As- \\ Syafi'iyah Indonesia
}

\author{
Nursanita Nasution \\ Nursanita1@gmail.com \\ Sekolah Tinggi IImu \\ Ekonomi Indonesia
}

\begin{abstract}
This study aims to determine: (1) the differences in student smash learning outcomes with leg power training and those not taught using leg power training, (2) the effect of the interaction between power leg and learning interest on smash learning outcomes in students, (3) differences in smash learning outcomes of students who have high interest in learning taught by power leg training with students not taught using leg power training, (4) differences in smash learning outcomes in students who have low learning interest taught by power leg training with students who are not taught using leg power training. This study uses an experimental method with a $2 \times 2$ factorial design. The population is grade VI students of SDN Margajaya I, Bekasi City with a total of 50 students. The sample consisted of $27 \%$ of the groups having high interest, while $27 \%$ of the groups having low interest. The conclusions of the results of the study are: smash learning outcomes of students who get treated with leg power training is higher than students who do not use leg power training. There is an interaction between power leg training with interest in learning towards smash learning outcomes. Smash learning outcomes of students taught using leg power training are higher than students who are taught without using leg power training in students who have high learning interest. Learning Outcomes Students who have low learning interest who are taught using leg power training are lower than those who do not use leg power training.
\end{abstract}

Keywords: leg power, interest in learning, smash learning outcomes

\begin{abstract}
Abstrak: Penelitian ini bertujuan untuk mengetahui:(1) perbedaan hasil belajar smash siswa dengan latihan power tungkai dan yang tidak diajar menggunakan latihan power tungkai,(2) pengaruh interaksi antara power tungkai dan minat belajar terhadap hasil belajar smash pada siswa,(3) perbedaan hasil belajar smash siswa yang memiliki minat belajar tinggi yang diajar dengan latihan power tungkai dengan siswa yang tidak diajar menggunakan latihan power tungkai,(4) perbedaan hasil belajar smash siswa yang memiliki minat belajar rendah yang diajar dengan latihan power tungkai dengan siswa yang tidak diajar menggunakan latihan power tungkai. Penelitian ini menggunakan metode eksperimen dengan rancangan faktorial $2 \times 2$. Populasinya adalah siswa kelas VI SDN Margajaya I Kota Bekasi yang berjumlah 50 siswa. Sampel berjumlah 27\%
\end{abstract}


kelompok yang memiliki minat tinggi, sedangkan $27 \%$ kelompok yang memiliki minat rendah. Kesimpulan dari hasil penelitian adalah: hasil belajar smash siswa yang mendapat perlakukan latihan power tungkai lebih tinggi dari siswa yang tidak menggunakan latihan power tungkai. Terdapat interaksi antara latihan power tungkai dengan minat belajar terhadap hasil belajar smash. Hasil belajar smash siswa yang diajar menggunakan latihan power tungkai lebih tinggi dibandingkan dengan siswa yang diajar tanpa menggunakan latihan power tungkai pada siswa yang mempunyai minat belajar tinggi. Hasil belajar Siswa yang mempunyai minat belajar rendah yang diajar menggunakan latihan power tungkai lebih rendah dari yang yang tidak menggunakan latihan power tungkai.

Kata kunci : power tungkai, minat belajar, hasil belajar smash

\section{PENDAHULUAN}

Salah satu tujuan pelaksanaan pendidikan jasmani, olahraga dan kesehatan di sekolah dasar adalah meningkatkan kemampuan dan keterampilan gerak dasar siswa. Gerak dasar jalan, lari dan lompat merupakan gerak dasar lokomotor yang perlu dikembangkan di sekolah dasar (SD) disamping gerak dasar lainnya (Hanief \& Sugito, 2015). Teknik bermain pada permainan bolavoli terdiri atas teknik service, passing, smash dan block (T, Cholik M, M Muhyi, 2012)

Faktor yang menyebabkan permainan bola voli kurang diminati di sekolah dasar, yaitu: bolanya terlalu berat sehingga menyebabkan tangan sakit dan membuat siswa takut memainkannya dan sarana dan prasarana yang kurang memadai. Salah satu masalah pokok dalam pembelajaran pada pendidikan formal (sekolah) adalah masih rendahnya daya serap siswa. Khusus mata pelajaran pendidikan jasmani olahraga dan kesehatan parameternya adalah rata - rata hasil belajar siswa yang senantiasa masih di bawah kriteria ketuntasan minimal.

Tabel 1. Nilai Keterampilan Olahraga Bola Voli Kelas VI SDN Margajaya I

\begin{tabular}{ccccc}
\hline No & Tahun Ajaran & $\begin{array}{c}\text { Rata - Rata } \\
\text { Nilai }\end{array}$ & KKM & Keterangan \\
\hline 1 & $2016 / 2017$ & 69 & 75 & Belum Tuntas \\
\hline 2 & $2017 / 2018$ & 70 & 75 & Belum Tuntas \\
\hline 3 & $2018 / 2019$ & 71 & 75 & Belum Tuntas \\
\hline
\end{tabular}

Kenyataan yang terjadi di kelas VI SDN Margajaya Kota Bekasi hasil belajar bola voli masih rendah. Hal ini dapat dilihat dari tabel 1 bahwa di SDN Margajaya Kota Bekasi dalam 3 tahun terakhir rata - rata hasil belajar bola voli kelas VI belum mencapai KKM. Penguasaan teknik dasar smash bola voli pada siswa kelas VI sangat rendah, ini tebukti dengan hasil tes yang telah dilakukan. Kriteria pencapaian smash yang 
baik pada bola voli telah ditentukan oleh guru, yaitu pukulan smash siswa tersebut harus bisa melewatkan bola dari atas net serta masuk ke daerah lapangan lawan dan penempatan bola yang tepat. Sedangkan realita yang terjadi yaitu siswa masih banya yang tidak bisa melewatkan bola dari atas net dan masih banyak perkenaan yang kurang tepat sehingga bola tersebut menyangkut ke net dan keluar lapangan.

Faktor fisik yaitu yang berkaitan dengan struktur, postur dan kemampuan biomotorik yang ditentukan secara genetik. Ada faktor yang sering kali sulit dibina dan dikembangkan, misalnya panjang lengan seseorang. Namun aspek lain seperti kemampuan biomotorik yang meliputi kekuatan, kecepatan, daya ledak, daya tahan dan sebagainya masih mungkin dibina dan dikembangkan sesuai dengan batas-batas kemampuan yang ada, terutama pada atlet-atlet muda yang masih dapat tumbuh dan berkembang. Sebagaimana temuan Pranopik dalam penelitian nya bahwa (1) Diperlukan variasi latihan smash yang dikembangkan agar dapat meningkatkan kemampuan smash atlet. (2) Dengan variasi latihan smash yang dikembangkan, atlet yang berlatih lebih efektif dan lebih efesien. (3) Dengan variasi latihan smash yang dikembangkan atlet lebih termotivasi dalam suasana latihan (Pranopik, 2017). Variasi latihan dibutuhkan agar koordinasi gerakan menjadi lebih baik, sebaiamana yang diungkapkan oleh Kristriawan dan Sukadiyanto bahwa Gerakan smash bila diuraikan terdiri atas awalan, menolak untuk melompat, memukul dan mendarat. Untuk melakukan beberapa unsur gerakan tersebut secara baik dan harmonis diperlukan kemampuan koordinasi gerakan yang baik dan pada saat memukul bola dibutuhkan koordinasi mata tangan yang baik (Kristriawan \& Sukadiyanto, 2016).

Berkaitan dengan prestasi olahraga, kemampuan - kemampuan biomotorik tersebut harus dibina dan dikembangkan sesuai dengan kekhususan cabang olahraga masing - masing. Salah satunya adalah kemampuan power otot tungkai. Power otot tungkai merupakan unsur dalam lepas tapak (tolakan) yang mengandung pengertian suatu kemampuan otot tungkai untuk melakukan gerakan menghentak (eksplosif) dengan membawa beban berat yang selanjutnya melakukan gerakan melayang kedepan dan keatas. Bukan hanya dalam Smash bola voly,olahraga taekwondo juga mengutamakan latihan power tungkai ini, sebagaimana yang di sarankan oleh..setelah diamelakukan penelitiannya yaitu: Bagi pelatih taekwondo kiranya dalam melatih atlet memperhatikan unsur biomotorik keseimbangan dan power otot tungkai khususnya dalam melatih teknik dasar tendangan dollyo chagi (Ariansyah, Insanistyo, \& Sugiyanto, 2017). Penelitian lain terkait dengan bola voli menyatakan bahwa tidak terdapat pengaruh yang signifikan dari latihan double leg boun terhadap peningkatan kemampuan smash pada ekstrakurikuler bola voli putra SMK N 1 Kota Jambi (Indrayana, 2018) 
Dalam permainan bola voli, power tungkai diperlukan pada saat akan melakukan smash (RAHADIAN, 2019). Berdasarkan penelitian empirik, dapat dikatakan bahwa power tungkai merupakan salah satu variabel yang sangat penting dan berpengaruh langsung terhadap keterampilan smash dalam bola voli.

Kegiatan belajar di sekolah akan lebih bergairah apabila seorang siswa mempunyai minat belajar yang kuat terhadap salah satu mata pelajaran, contohnya minat belajar terhadap mata pelajaran penjas orkes. Maka, siswa itu akan terus menerus untuk mengikuti pelajaran penjas orkes dengan perasaan yang senang dan siswa pun akan mendapatkan nilai yang baik juga. Minat bisa timbul, karena adanya dorongan yang kuat dari diri sendiri. Minat timbul bukan hanya dari diri sendiri tetapi ada dorongan yang kuat dari keluarga dan lingkungan sosial masyarakat. Dalam kegiatan belajar, minat berperan sebagai kekuatan yang akan mendorong siswa untuk belajar, berbeda dengan siswa yang hanya menerima pelajaran yang hanya tergerak untuk mau belajar tanpa ada minat yang ada dalam dirinya (Eva \& Siagian, 2012). Musa dan Khasanah menyimpulkan dalam penelitiannya bahwa diperlukan Upaya memberikan pelayanan pembelajaran berdasarkan karakteristik siswa. Temuan dalam penelitian ini menunjukan bahwa hasil belajar prakarya dan kewirausahaan kelompok siswa yang memiliki minat belajar tinggi berbeda dengan kelompok siswa yang memiliki minat belajar rendah, secara umum minat siswa yang memiliki minat belajar tinggi memperoleh nilai lebih tinggi dari pada siswa yang memiliki minat belajar rendah (Musa \& Khasanah, 2019). Hasil belajar akuntansi yang mempunyai minat belajar tinggi dan diajar menggunakan strategi pembelajaran e-learning lebih tinggi dari pada hasil belajar akuntansi yang di ajar menggunakan strategi ekspositori (Kristiyani \& Budiningsih, 2019).

Peneliti berharap agar latihan power tungkai akan meningkatkan hasil smash bola voli. Namun ingin melakukan penelitian yang lebih mendalam terkait dengan perlakuan latihan power tungkai dan minat belajar terhadap hasil belajar smash bola voli. Dari uraian tersebut maka peneliti tertarik untuk melakukan penelitian dengan judul Pengaruh Power Tungkai Dan Minat Terhadap Kemampuan Smash pada Siswa Kelas VI SDN Margajaya I.

\section{METODE}

Dalam penelitian ini menggunakan metode eksperimen dengan menggunakan rancangan grup faktorial $2 \times 2$. Populasi dalam penelitian ini adalah siswa kelas VI SDN Margajaya yang berjumlah 50 orang. Sebanyak $27 \%$ kelompok atas akan dinyatakan sebagai kelompok yang memiliki minat tinggi. Sedangkan 27\% kelompok bawah akan dinyatakan sebagai kelompok yang memiliki minat rendah. berdasarkan teori Guilford 
maka dalam penentuan kelompok siswa yang memiliki minat tinggi dan rendah diperoleh $27 \%$ dari jumlah siswa dikelas yang berjumlah 8 orang. Data atau informasi yang sudah dikumpulkan melalui alat pengumpul data, selanjutnya akan dianalisis melalui teknik ANAVA $2 \times 2$. Namun, sebelumnya agar uji hipotesis dapat dilakukan perlu dilakukan uji persyaratan, yakni uji normalitas dan uji Homogenitas data.

Uji normalitas dan uji homogenitas data menggunakan SPSS. Uji Normalitas data menggunakan SPSS dilakukan dengan uji KolmogorovSmirnov. Uji homogenitas data menggunakan SPSS dengan uji Leverne's. Jika analisis data menunjukkan adanya pengaruh interaksi antara metode pembelajaran dan disiplin terhadap hasil belajar bola voli, lalu diteruskan dengan uji Tukey.

\section{HASIL}

Deskripsi penelitian menjelaskan gambaran umum karakteristik data hasil penelitian hasil belajar peserta didik kelas VI SDN Marajaya I untuk kelompok eksperimen maupun kelompok kontrol

Tabel 2 Rekapitulasi Hasil Perhitungan Skor Hasil Belajar Smash Pada Setiap Kelompok

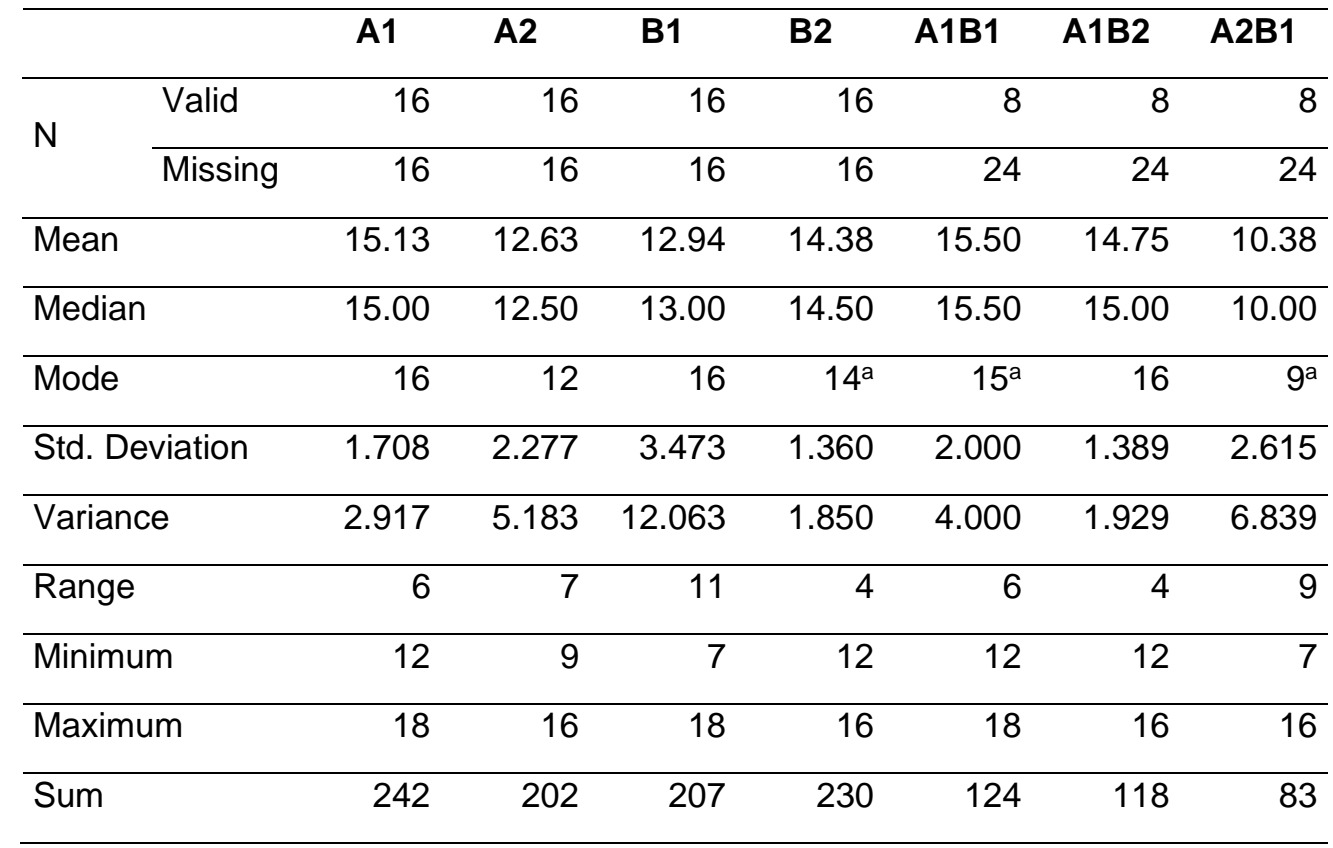

Tabel 2 di atas menerangkan bahwa A1 (kelompok siswa yang mengikuti pelajaran dengan mengunakan latihan power tungkai), A2 (kelompok siswa yang mengikuti pelajaran tanpa latihan), B1 (kelompok siswa yang memiliki minat belajar tinggi), B2 (kelompok siswa yang memiliki minat belajar rendah), A1B1 (kelompok siswa yang mengikuti 
pelajaran dengan latihan power tungkai yang memiliki minat belajar tinggi), A2B1 (kelompok siswa yang mengikuti pelajaran non latihan power tungkai yang memiliki minat belajar tinggi), A1B2 (kelompok siswa yang mengikuti pelajaran dengan latihan yang memiliki minat belajar rendah), A2B2 (kelompok siswa yang mengikuti pelajaran non latihan power tungkai yang memiliki minat belajar rendah).

Sebelum melakukan uji hipotesis, terlebih dahulu dilakukan uji prasyarat analisis data yaitu uji normalitas dan homogenitas data.. Pengujian normalitas untuk mengukur masing - masing kelas Eksperimen dan Kelas Kontrol dari populasi berdistribusi normal. Pengujia normal atau tidaknya data pada penelitian ini menggunakan statistik SPSS melalui uji Kolomogorov - Smirnov dan Shapiro - Wilk. Hipotesis statistik yang diajukan untuk pengujian normalitas adalah sebagai berikut: Ho: Data berdistribusi normal, Hi: Data tidak berdistribusi normal. Kriteria uji: Ho diterima dan Hi ditolak jika Sig $>0.05$, Ho ditolak dan Hi diterima jika Sig $<0.05$.

Table 3 Hasil Uji Normalitas Variable A1 Dan A2

\begin{tabular}{lrrrrrrr}
\hline & A & \multicolumn{2}{c}{ Kolmogorov-Smirnova $^{\mathbf{a}}$} & \multicolumn{3}{c}{ Shapiro-Wilk } \\
\cline { 2 - 9 } & & Statistic & Df & Sig. & Statistic & df & Sig. \\
\hline \multirow{2}{*}{ Hasil } & 1 & .179 & 16 & .180 & .922 & 16 & .181 \\
\cline { 2 - 8 } & 2 & .108 & 16 & $.200^{*}$ & .950 & 16 & .485
\end{tabular}

Berdasarkan tabel 3 pada kolom Kolomogorov- Smirnov dan Shapiro - Wilk dapat diketahui nilai signifikan setelah dilakukan pengolahan data pada SPSS maka diperoleh output nilai sig untuk A1 sebesar 0.181 dan A2 sebesar 0.485 berarti nilai sig A1 lebih besar dari nilai $\alpha(0.181>0.05)$ dan nilai sig A2 lebih besar dari nilai $\alpha(0.485>0.05)$, maka Ho diterima dengan demikian data berdistribusi normal.

Tabel 4 Hasil Uji Normalitas Variable B1 Dan B2

\begin{tabular}{lccccccc}
\hline & B & \multicolumn{2}{c}{ Kolmogorov-Smirnova $^{\mathbf{a}}$} & \multicolumn{3}{c}{ Shapiro-Wilk } \\
\cline { 2 - 8 } & & Statistic & Df & Sig. & Statistic & df & Sig. \\
\hline \multirow{2}{*}{ Hasil } & 1 & .176 & 16 & .199 & .930 & 16 & .246 \\
\cline { 2 - 8 } & 2 & .177 & 16 & .193 & .901 & 16 & .084 \\
\hline
\end{tabular}

Berdasarkan tabel 4 pada kolom Kolomogorov- Smirnov dan Shapiro - Wilk dapat diketahui nilai signifikan setelah dilakukan pengolahan data pada SPSS maka diperoleh output nilai sig untuk B1 sebesar 0.246 dan B2 sebesar 0.084 berarti nilai sig B1 lebih besar dari nilai a $(0.246>0.05)$ dan nilai sig B2 lebih besar dari nilai $\alpha(0.084>0.05)$, maka Ho diterima dengan demikian data berdistribusi normal. 
Tabel 5 Hasil Uji Normalitas Variable A1B1, A2B1, A1B2, dan A2B2

\begin{tabular}{|c|c|c|c|c|c|c|c|}
\hline & \multirow[t]{2}{*}{$\mathbf{C}$} & \multicolumn{3}{|c|}{ Kolmogorov-Smirnova } & \multicolumn{3}{|c|}{ Shapiro-Wilk } \\
\hline & & Statistic & Df & Sig. & Statistic & df & Sig. \\
\hline \multirow{4}{*}{ Hasil } & 1 & .151 & 8 & $.200^{*}$ & .939 & 8 & .600 \\
\hline & 2 & .196 & 8 & $.200^{*}$ & .858 & 8 & .114 \\
\hline & 3 & .245 & 8 & .175 & .863 & 8 & .128 \\
\hline & 4 & .152 & 8 & $.200^{*}$ & .965 & 8 & .857 \\
\hline
\end{tabular}

Berdasarkan tabel 5 pada kolom Kolomogorov- Smirnov dan Shapiro - Wilk dapat diketahui nilai signifikan setelah dilakukan pengolahan data pada SPSS maka diperoleh output nilai sig untuk A1B1 sebesar 0.600, A2B1 sebesar 0.128., A1B2 sebesar 0.114 dan A2B2 sebesar 0.857 Berarti nilai sig A1B1 lebih besar dari nilai a $(0.600>0.05)$, nilai sig A2B1 lebih besar dari nilai a $(0.128>0.05)$, sig A1B2 lebih besar dari nilai a $(0.114>0.05)$, nilai sig A2B2 lebih besar dari nilai a $(0.857>$ 0.05), maka Ho diterima dengan demikian data berdistribusi normal.

Uji homogenitas bertujuan untuk melihat apakah data pada kedua kelas memiliki variansi yang sama (homogen) atau tidak. (1) Jika nilai probabilitas (nilai Sig) $>0.05$ atau $\mathrm{F}$ hitung $<\mathrm{F}$ tabel, maka data pada kedua kelas memiliki variansi yang sama (homogen). (2) Jika nilai probabilitas (nilai Sig) $<0.05$ atau $\mathrm{F}$ hitung $>\mathrm{F}$ tabel, maka data pada kedua kelas memiliki variansi yang sama (tidak homogen).

Hipotesis statistik yang diajukan dalam pengujian homogenitas adalah sebagai berikut: $\mathrm{Ho}$ : Variansi Homogen dan $\mathrm{Hi}$ :Variansi Tidak homogeny. Kriteria uji: Ho diterima dan $\mathrm{Hi}$ ditolak jika Sig $>0.05$, Ho ditolak dan Hi diterima jika Sig $<0.05$.

Uji homogenitas dilakukan pada dua kelompok yang dibandingkan yaitu kelas eksperimen dan kelas control. Di bawah ini adalah uji homogenitas data pada media pembelajaran (A1 dan $A 2)$, data minat belajar (B1 dan B2) dan data rancangan penelitian (A1B1, A2B1, A1B2, dan A2B2). Hasil uji homogenitas data hasil belajar smash dapat dilihat pada tabel berikut ini:

Tabel 6 Uji Homogenitas

\begin{tabular}{llrrrr}
\hline & \multicolumn{2}{l}{$\begin{array}{l}\text { Levene } \\
\text { Statistic }\end{array}$} & df1 & df2 & \multicolumn{1}{c}{ Sig. } \\
\hline \multirow{2}{*}{ Hasil } & Based on Mean & 2.249 & 1 & 30 & .144 \\
\cline { 2 - 6 } & Based on Median & 2.301 & 1 & 30 & .140 \\
\hline
\end{tabular}


Based on Median and with

adjusted df

Based on trimmed mean

2.301

1

29.864

.140

Berdasarkan tabel 6 menunjukkan nilai berarti sig variabel kelas ekpserimen dan kelas kontrol sebesar 0.144 lebih besar dari nilai $\alpha=0.05$ (0.144.> 0.05). Dengan demikian Ho diterima. Maka dapat disimpulkan bahwa data A1 dan A2 homogen. Dengan demikian persyaratan normalitas dan homogenitas data lebih terpenuhi dan selanjutnya dilakukan analisis variansi (ANAVA) dalam pengujian hipotesis penelitian.

Perumusan hipotesis pertama dalam penelitian ini adalah Ho: tidak terdapat perbedaan hasil belajar smash antara kelompok siswa yang diajar menggunakan latihan kekuatan tungkai dengan kelompok siswa yang tidak diajar menggunakan latihan kekuatan tungkai, Hi: hasil belajar smash kelompok siswa yang diajar menggunakan latihan kekuatan tungkai lebih tinggi dibandingkan dengan kelompok siswa yang tidak diajar menggunakan latihan kekuatan tungkai. Hipotesis statistik: Ho: $\mu \mathrm{A} 1=$ $\mu \mathrm{A} 2$, Hi: $\mu \mathrm{A} 1>\mu \mathrm{A} 2$. Pengujian hipotesis menggunakan tingkat signifikan 0.05 dengan kriteria pengujian:Nilai $F_{\text {hitung }}<F_{\text {tabel }}$ atau nilai sig $>\alpha=0.05$, maka Ho diterima, Nilai $F_{\text {hitung }}>F_{\text {tabel }}$ atau nilai sig $<\alpha=0.05$, maka Ho ditolak

Tabel 7 Uji Hipotesis 1 dan Hipotesis 2

Dependent Variable: Hasil

\begin{tabular}{lrrrrr}
\hline Source & $\begin{array}{c}\text { Type III Sum of } \\
\text { Squares }\end{array}$ & Df & Mean Square & F & Sig. \\
\hline Corrected Model & $82.500^{\mathrm{a}}$ & 3 & 27.500 & 8.652 & .000 \\
\hline Intercept & 6160.500 & 1 & 6160.500 & 1938.135 & .000 \\
\hline $\mathrm{A}$ & 50.000 & 1 & 50.000 & 15.730 & .000 \\
\hline $\mathrm{B}$ & 8.000 & 1 & 8.000 & 2.517 & .124 \\
\hline $\mathrm{A}^{*} \mathrm{~B}$ & 24.500 & 1 & 24.500 & 7.708 & .010 \\
\hline Error & 89.000 & 28 & 3.179 & & \\
\hline Total & 6332.000 & 32 & & & \\
\hline Corrected Total & 171.500 & 31 & & & \\
\hline
\end{tabular}

Tabel 7 menunjukkan signifikan pengaruh latihan power tungkai yang diperoleh lebih kecil dari $\alpha=0.05(0.000<0.05)$. Dengan demikian bearti Ho ditolak, hal ini berarti Hi diterima menyatakan bahwa hasil belajar smash secara keseluruhan siswa yang diajar menggunakan latihan 
kekuatan tungkai lebih tinggi disbanding dengan siswa yang tidak diajar menggunakan latihan kekuatan tungkai.

Perumusan hipotesis kedua dalam penelitian ini adalah sebagai berikut: Ho: tidak terdapat interaksi antara siswa yang diajar menggunakan latihan kekuatan tungkai dengan minat belajar terhadap hasil belajar smash, Hi: terdapat interaksi antara siswa yang diajakan menggunakan latihan kekuatan tungkai dengan minat belajar terhadap hasil belajar smash. Hipotesis statistik: Ho : Int. $A \times B=0, H i:$ Int $A \times B \neq 0$. Pengujian hipotesis menggunakan tingkat signifikan 0.05 dengan kriteria pengujian: Nilai $F_{\text {hitung }}<F_{\text {tabel }}$ atau nilai sig $>\alpha=0.05$, maka Ho diterima dan Nilai $F_{\text {hitung }}>F_{\text {tabel }}$ atau nilai sig $<\alpha=0.05$, maka Ho ditolak.

Tabel 7 menunjukkan adanya interaksi antara latihan kekuatan tungkai dengan minat belajar diperoleh lebih kecil dari $\alpha=0.05(0.010<$ 0.05). Dengan demikian bearti Ho ditolak, hal ini berarti Hi diterima menyatakan terdapat interkasi antara siswa yang diajar menggunakan latihan kekuatan tungkai dengan minat belajar terhadap hasil belajar smash. Oleh karena adanya interaksi antara variabel terbukti secara signifikan, maka langkah berikutnya melakukan pengujian untuk menentukan kebermaknaan interaksi ini dengan menggunakan uji anava dilanjutkan dengan uji tukey atau uji lanjut yang diperlukan sebagai pengajuan hipotesis ketiga dan keempat.

Uji tukey digunakan sebagai uji lanjutan untuk melihat perbedaan pengaruh antara latihan kekuatan tungkai dan minat belajar, yaitu antara kelompok siswa yang diajar menggunakan latihan power tungkai dan kelompok siswa yang tidak diajar menggunakan kekuatan tungkai dilihat dari minat bejar tinggi (A1B1 dan A2B1). Perumusan hipotesis ketiga dalam penelitian ini adalah sebagai berikut: Ho : tidak terdapat perbedaan hasil belajar smash kelompok siswa yang diajar menggunakan latihan kekuatan tungkai dibandingkan dengan kelompok siswa yang tidak diajar menggunakan latihan kekuatan tungkai pada peserta didik yang mempunyai minat belajar tinggi, $\mathrm{Hi}$ : hasil belajar smash siswa yang mempunyai minat belajar tinggi dan diajar menggunakan latihan kekuatan tungkai lebih tinggi dibandingkan dengan yang diajar tidak menggunakan latihan kekuatan tungkai. Hipotesis statistik $\mathrm{Ho}: \mu \mathrm{A} 1 \mathrm{~B} 1=\mu \mathrm{A} 2 \mathrm{~B} 1$ dan $\mathrm{Hi}$ : $\mu A 1 B 1>\mu A 2 B 1$. Pengujian hipotesis menggunakan kriteria pengujian: Nilai $F_{\text {hitung }}<\mathrm{F}_{\text {tabel }}$ atau nilai sig $>\alpha=0.05$, maka Ho diterima, Nilai F hitung $>$ $F_{\text {tabel }}$ atau nilai sig $<\alpha=0.05$, maka Ho ditolak

Tabel 8 Uji Tukey

Dependent Variable: Hasil

Tukey HSD

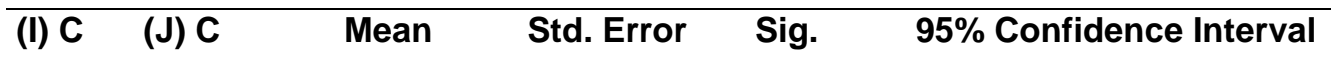




\begin{tabular}{|c|c|c|c|c|c|c|}
\hline & \multicolumn{3}{|c|}{$\begin{array}{c}\text { Difference (I- } \\
\mathrm{J})\end{array}$} & \multicolumn{2}{|r|}{$\begin{array}{l}\text { Lower } \\
\text { Bound }\end{array}$} & Upper Bound \\
\hline & 2 & .75 & .891 & .834 & -1.68 & 3.18 \\
\hline \multirow[t]{3}{*}{1} & 3 & $4.25^{*}$ & .891 & .000 & 1.82 & 6.68 \\
\hline & 4 & 1.50 & .891 & .351 & -.93 & 3.93 \\
\hline & 1 & -.75 & .891 & .834 & -3.18 & 1.68 \\
\hline \multirow[t]{3}{*}{2} & 3 & $3.50^{*}$ & .891 & .003 & 1.07 & 5.93 \\
\hline & 4 & .75 & .891 & .834 & -1.68 & 3.18 \\
\hline & 1 & $-4.25^{*}$ & .891 & .000 & -6.68 & -1.82 \\
\hline \multirow[t]{3}{*}{3} & 2 & $-3.50^{*}$ & .891 & .003 & -5.93 & -1.07 \\
\hline & 4 & $-2.75^{*}$ & .891 & .022 & -5.18 & -.32 \\
\hline & 1 & -1.50 & .891 & .351 & -3.93 & .93 \\
\hline \multirow[t]{2}{*}{4} & 2 & -.75 & .891 & .834 & -3.18 & 1.68 \\
\hline & 3 & $2.75^{*}$ & .891 & .022 & .32 & 5.18 \\
\hline
\end{tabular}

Perhitungan yang terdapat pada tabel 8 diatas menunjukkan nilai sig $=0.00$ lebih kecil dari $\alpha=0.05(0.00<0.05)$. Dengan demikian berarti Ho ditolak, hal ini berate $\mathrm{Hi}$ diterima yang menyatakan bahwa hipotesis ketiga pada penelitian ini teruji kebenarannya setelah data diolah melalui perhitungan uji anava dan dilanjutkan dengan uji tukey. Dimana hasil belajar smash kelompok siswa yang diajar menggunakan latihan kekuatan tungkai secara signifikan lebih tinggi dibandingkan dengan yang diajar tidak menggunakan latihan kekuatan tungkai pada siswa yang mempunyai minat belajar tinggi.

Uji tukey digunakan sebagai uji lanjutan untuk melihat perbedaan pengaruh antara latihan power tungkai dan minat belajar, yaitu antara kelompok siswa yang diajar menggunakan latihan kekuatan tungkai dan kelompok siswa yang tidak diajar menggunakan kekuatan tungkai dilihat dari minat bejar rendah (A1B2 dan A2B2). Perumusan hipotesis keempat dalam penelitian ini adalah sebagai berikut: Ho : tidak terdapat perbedaan hasil belajar smash kelompok siswa yang diajar menggunakan latihan kekuatan tungkai dibandingkan dengan kelompok siswa yang tidak diajar menggunakan latihan kekuatan tungkai pada peserta didik yang mempunyai minat belajar rendah. Hi : hasil belajar smash siswa yang mempunyai minat belajar rendah dan diajar menggunakan latihan kekuatan tungkai lebih rendah dibandingkan dengan yang diajar tidak menggunakan latihan kekuatan tungkai. Hipotesis statistik: Ho: $\mu \mathrm{A} 1 \mathrm{~B} 2=$ $\mu \mathrm{A} 2 \mathrm{~B} 2, \mathrm{Hi}: \mu \mathrm{A} 1 \mathrm{~B} 2>\mu \mathrm{A} 2 \mathrm{~B} 2$. Pengujian hipotesis menggunakan kriteria pengujian: Nilai $F_{\text {hitung }}<F_{\text {tabel }}$ atau nilai sig $>\alpha=0.05$, maka Ho diterima, Nilai $F_{\text {hitung }}>F_{\text {tabel }}$ atau nilai sig $<\alpha=0.05$, maka Ho ditolak. 
Perhitungan yang terdapat pada tabel 8 di atas menunjukkan nilai sig $=$ 0.834 lebih besar dari $\alpha=0.05(0.834>0.05)$. Dengan demikian berarti Ho diterima, hipotesis pada penelitian ini teruji kebenarannya setelah data diolah melalui perhitungan uji anava dan dilanjutkan dengan uji tukey. Dimana tidak terdapat perbedaan hasil belajar smash kelompok siswa yang diajar menggunakan latihan power tungkai dibandingkan dengan kelompok siswa yang tidak diajar menggunakan latihan power tungkai pada peserta didik yang mempunyai minat belajar rendah kelompok siswa yang diajar menggunakan latihan kekuatan tungkai secara signifikan lebih rendah dibandingkan dengan yang diajar tidak menggunakan latihan kekuatan tungkai pada siswa yang mempunyai minat belajar rendah.

\section{PEMBAHASAN}

Berdasarkan hasil pengujian hipotesis yang telah dipaparkan di atas, keempat hipotesis yang diajukan secara signifikan dapat diterima. Uraian masing - masing penerimaan keempat hipotesis yang dimaksud dapat diberikan pembahasan sebagai berikut:

Hipotesis satu, hasil belajar smash siswa yang diajarkan menggunakan latihan kekuatan tungkai lebih tinggi dibandingkan dengan siswa yang tidak diajarkan menggunakan kekuatan tungkai. Dari hasil perhitungan antara hasil belajar smash yang mendapat perlakuan dengan menggunakan latihan kekuatan tungkai dan tidak menggunakan latihan didapatkan hasil: Nilai signifikan hasil uji anava sebesar 0.000 , hal ini menunjukkan bahwa nilai signifikannya lebih kecil dari $\alpha=0.05$. Sehingga Ho ditolak dan Hi diterima. Maka hasil belajar smash siswa yang mendapat perlakukan latihan kekuatan tungkai lebih tinggi dari hasil belajar smash siswa yang tidak menggunakan latihan kekuatan tungkai. Power memberikan suatu kontribusi terhadap otot tungkai, di mana pada saat akan melompat, otot tungkai akan menghasilkan kerja secara cepat dan kuat atau secara eksplosif, dan biasanya kerja otot ini berlangsung dalam keadaan yang bergerak atau dinamis, karena pada saat melompat akan bergerak berpindah tempat (Achmad, 2016). Lompatan yang tinggi dihasilkan dari kerja otot tungkai yang secara eksplosif dapat memberikan dampak yang maksimal. Ada perbedaan kelincahan bulutangkis antara mahasiswa yang memiliki powerotot tungkai tinggi dan rendah. Peningkatan kelincahan bulutangkis pada mahasiswa yang memiliki power otot tungkai tinggi lebih baik dari pada yang memiliki power otot tungkai rendah(Trihadi Karyono, 2016)

Lompatan pada saat melakukan tolakan lompat jauh merupakan kemampuan dari otot yang bekerja secara cepat dan kuat. Oleh sebab itu, pada saat melompat sudah tentu harus bergerak lebih cepat karena pada saat di udara memiliki waktu yang tidak banyak dalam melayang hingga mendarat. Untuk itu pula otot tungkai harus juga kuat dengan cara dilatih 
secara teratur dan terarah. Pada saat itulah kontribusi power dilakukan dalam kemampuan tingginya lompatan.

Hipotesis kedua, terdapat pengaruh interaksi antara latihan power tungkai dan minat belajar siswa terhadap hasil belajar smash. Dari hasil perhitungan antara siswa yang mendapat latihan power tungkai dan minat belajar siswa terhadap hasil belajar smash didapatkan hasil: nilai signifikan hasil uji anava sebesar 0.003, hal ini menunjukkan nilai signifikannya lebih kecil dari $\alpha=0.05$. Sehingga Ho ditolak dan $\mathrm{Hi}$ diterima, hal ini berarti terdapat interaksi antara latihan power tungkai dengan minat belajar terhadap hasil belajar smash.

Perbedaan hasil belajar smash antara siswa yang diajar menggunakan latihan power tungkai dengan yang tidak diajar menggunakan latihan power tungkai pada siswa yang memiliki minat belajar yang tinggi. Dari hasil perhitungan perbedaan pengaruh antara kelompok siswa yang diajar menggunakan latihan power tungkai dan kelompok siswa yang tidak diajar menggunakan latihan power tungkai dilihat dari minat belajar tinggi (A1B1 dan A2B2), didapatkan hasil: nilai signifikan hasil uji anava sebesar 0.00 , hal ini menunjukkan bahwa taraf signifikannya lebih kecil dari taraf signifikan $\alpha=0.05$. Sehingga Ho ditolak dan Hi diterima.

Hal ini berarti terdapat perbedaan yang signifikan antara hasil belajar smash siswa yang diajar menggunakan latihan power tungkai dengan siswa yang diajar tidak menggunakan latihan power tungkai pada siswa yang mempunyai minat belajar tinggi. Hasil analisis ini dibuktikan dari perbedaan rerata hasil belajar dari hasil belajar smash siswa yang diajar menggunakan latihan power tungkai dengan siswa yang diajar tidak menggunakan latihan power tungkai pada peserta yang mempunyai minat belajar tinggi. Rerata hasil belajar $\mathrm{A} 1 \mathrm{~B} 1=15.50$ sedangkan untuk rerata hasil belajar A2B1 $=10.38$. Temuan ini didukung oleh penelitian Ahmad menemukan bahwa semakin power tungkai, koordinasi mata-tangan dan rasa percaya diri pemain bola voli, makin baik pula hasil keterampilan open spike pada pemain bola voli. Sebaiknya, makin rendah power tungkai, koordinasi mata-tangan dan rasa percaya diri pemain bola voli, makin rendah pula hasil keterampilan open spike pada olahraga bola voli. Oleh karena itu, power tungkai, koordinasi mata-tangan dan rasa percaya diri merupakan tiga variabel yang perlu diperhatikan untuk mendapatkan hasil keterampilan open spike dalam olahraga bola voli, walaupun salah satu dari ketiga variabel tersebut hanya sebagai pendukung (Achmad, 2016).

Hipotesis ketiga, menunjukkan bahwa hasil belajar smash siswa yang diajar menggunakan latihan power tungkai lebih tinggi dibandingkan dengan siswa yang diajar tanpa menggunakan latihan power tungkai dilihat dari rerata hasil belajar siswa yang mempunyai minat belajar tinggi. Hal ini sejalan dengan penelitian Eva, Roida dan Siagian, Flora yang mengatakan siswa yang memiliki minat tinggi akan cendrung tekun, ulet, 
semangat dalam belajar, pantang menyerah dan senang menghadapi tantangan. Hal ini sangatlah wajar karena untuk mendapatkan minat belajar tinggi dibutuhkan ketekunan yang tinggi, besar kontribusi pengaruh prestasi belajar matematika terhadap minat siswa dilakukan dengan menggunakan uji koefisien determinasi, dari perhitungan didapat $\mathrm{KD}=$ $12,05 \%$, Jadi pengaruh prestasi belajar matematika terhadap minat belajar sebesar $12,05 \%$ dan sisanya dipengaruhi oleh faktor lain (Eva \& Siagian, 2012).

\begin{abstract}
Perbedaan hasil belajar smash antara siswa yang diajar menggunakan latihan power tungkai dengan yang tidak diajar menggunakan latihan power tungkai pada siswa yang memiliki minat belajar yang rendah. Dari hasil perhitungan perbedaan pengaruh hasil belajar smash antara siswa yang diajar menggunakan latihan power tungkai dengan yang tidak diajar menggunakan latihan power tungkai pada siswa yang memiliki minat belajar rendah (A1B2 dan A2B2), didapatkan hasil: nilai signifikan hasil uji ANAVA sebesar 0.859, hal ini menunjukkan bahwa taraf signifikan tersebut $>\alpha=0.05$. Sehingga $\mathrm{H}_{0}$ ditolak dan $\mathrm{H}_{1}$ diterima.
\end{abstract}

Hal ini berarti tidak terdapat perbedaan hasil belajar smash kelompok siswa yang diajar menggunakan latihan power tungkai dibandingkan dengan kelompok siswa yang tidak diajar menggunakan latihan power tungkai pada peserta didik yang mempunyai minat belajar rendah kelompok siswa yang diajar menggunakan latihan power tungkai secara signifikan lebih rendah dibandingkan dengan yang diajar tidak menggunakan latihan power tungkai pada siswa yang mempunyai minat belajar rendah. Hasil analisis ini membuktikan bahwa perbedaan rerata hasil belajar smash siswa yang diajar menggunakan latihan power tungkai dengan yang tidak diajar menggunakan latihan power tungkai pada siswa yang memiliki minat belajar rendah. Rerata hasil belajar $\mathrm{A} 1 \mathrm{~B} 2=14.75$ sedangkan untuk rerata hasil belajar A2B2 $=14.00$. Pembahasan pada hipotesis keempat menunjukkan bahwa siswa yang mempunyai minat belajar rendah namun diberi perlakuan diajar menggunakan latihan power tungkai ketika proses belajar mengajar berlangsung tidak dapat memaksimalkan hasil belajar smash. Hal ini karena potensi minat belajar rendah tidak mendukung tercapainya pembelajaran yang optimal.

\title{
KESIMPULAN
}

Adapaun kesimpuan yang didapat dalam penelitian ini adalah

Pertama: Hasil belajar smash siswa dengan latihan power tungkai lebih tinggi daripada hasil belajar smash siswa tanpa latihan power tungkai pada siswa kelas VI SDN Margajaya. Kedua : terdapat pengaruh interaksi antara latihan power tungkai dan minat belajar siswa terhadap hasil belajar smash dalam permainan bola voli bagi siswa kelas VI SDN Margajaya. Ketiga : Hasil belajar smash siswa yang memiliki minat belajar tinggi yang diajar dengan latihan power tungkai lebih tinggi daripada siswa 
yang diajar tanpa menggunakan latihan power tungkai pada siswa kelas VI SDN Margajaya. Keempat: Hasil belajar smash siswa yang memiliki minat belajar rendah yang diajar dengan latihan power tungkai lebih rendah daripada siswa yang diajar tanpa menggunakan latihan power tungkai bagi siswa kelas VI SDN Margajaya.

\section{DAFTAR PUSTAKA}

achmad, I. Z. (2016). Hubungan Antara Power Tungkai, Koordinasi MataTangan, Dan Rasa Percaya Diri Dengan Hasil Keterampilan Open Spike Bola Voli. Jurnal Pendidikan Unsika, 4(1), 78-90.

Ariansyah, A., Insanistyo, B., \& Sugiyanto, S. (2017). Hubungan Keseimbangan Dan Power Otot Tungkai Terhadap Kemampuan Tendangan Dolly Chagi Pada Atlet Ukm (Unit Kegiatan Mahasiswa) Taekwondo Universitas Bengkulu. Kinestetik, 1(2), 111-116. Https://Doi.Org/10.33369/Jk.V1i2.3474

Eva, R., \& Siagian, F. (2012). Pengaruh Minat Dan Kebiasaan Belajar Siswa. Jurnal Formatif. Https://Doi.Org/Http://Dx.Doi.Org/10.30998/Formatif.V2i2.93

Hanief, Y. N., \& Sugito, S. (2015). Membentuk Gerak Dasar Pada Siswa Sekolah Dasar Melalui Permainan Tradisional. Jurnal Sportif: Jurnal Penelitian Pembelajaran, 1(1), 60-73. Https://Doi.Org/10.29407/Js_Unpgri.V1i1.575

Indrayana, B. (2018). Perbedaan Pengaruh Latihan Knee Tuck Jump Dengan Latihan Double Leg Bound Terhadap Peningkatan Power Otot Tungkai Dan Kemampuan Smash Pada Ekstrakurikuler Bola Voli Putra Smkn 1 Kota Jambi. Jorpres (Jurnal Olahraga Prestasi), 14(1), 1-23. Https://Doi.Org/10.21831/Jorpres.V14i1.19977

Kristiyani, E., \& Budiningsih, I. (2019). Pengaruh Strategi Pembelajaran ELearning Dan Minat Belajar Terhadap Hasil Belajar Akuntansi.

Akademika, 8(01), 81-100. Https://Doi.Org/10.34005/Akademika.V8i01.341

Kristriawan, A., \& Sukadiyanto, S. (2016). Pengaruh Metode Latihan Dan Koordinasi Terhadap Smash Backcourt Atlet Bola Voli Yunior Putra. Jurnal Keolahragaan, 4(2), 122-134. Https://Doi.Org/10.21831/Jk.V4i2.10890

Musa, \& Khasanah. (2019). Pengaruh Penggunaan Media E-Learning Berbasis Moodle Dan Minat Belajar Terhadap Hasil Belajar Prakarya Dan Kewirausahaan. Akademika Jurnal Teknologi Pendidikan, 8(01), 1-16. Https://Doi.Org/10.34005/Akademika.V8i01.332

Pranopik, M. R. (2017). Pengembangan Variasi Latihan Smash Bola Voli. 
Jurnal Prestasi, 1(1), 31-33. Https://Doi.Org/10.24114/Jp.V111.6495

Rahadian, R. (2019). Model Pembelajaran Smash Bolavoli Pada Siswa Sekolah Menengah Kejuruan. Biormatika : Jurnal IImiah Fakultas Keguruan Dan IImu Pendidikan.

Https://Doi.Org/10.35569/Biormatika.V5i01.412

T , Cholik M, M Muhyi, S. J. (2012). Permainan Bola Voli. Surabaya: Graha Pustaka Media Utama.

Trihadi Karyono. (2016). Pengaruh Metode Latihan Dan Power Otot Tungkai Terhadap Kelincahan Bulutangkis. Jurnal Olahraga Prestasi, 12(1), 49-62. 